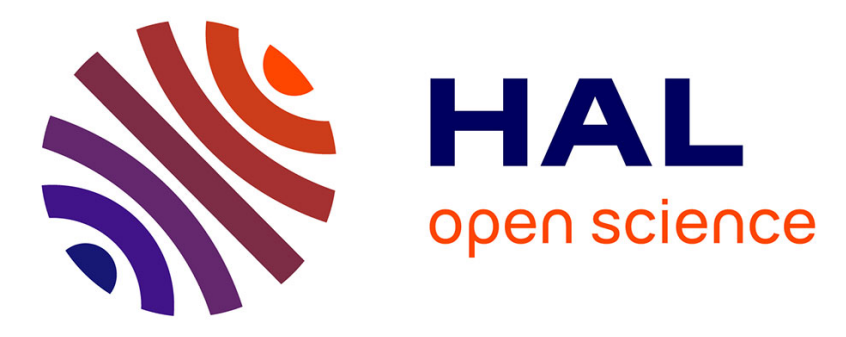

\title{
ICT and education : a critical role in human and social development
}

\author{
Saïd Assar, Redouane El Amrani, Richard T. Watson
}

\section{To cite this version:}

Saïd Assar, Redouane El Amrani, Richard T. Watson. ICT and education : a critical role in human and social development. Information Technology for Development, 2010, 16 (3), pp.151-158. 10.1080/02681102.2010.506051 . hal-00529533

\section{HAL Id: hal-00529533 https://hal.science/hal-00529533}

Submitted on 25 Oct 2010

HAL is a multi-disciplinary open access archive for the deposit and dissemination of scientific research documents, whether they are published or not. The documents may come from teaching and research institutions in France or abroad, or from public or private research centers.
L'archive ouverte pluridisciplinaire HAL, est destinée au dépôt et à la diffusion de documents scientifiques de niveau recherche, publiés ou non, émanant des établissements d'enseignement et de recherche français ou étrangers, des laboratoires publics ou privés. 


\title{
ICT and education: A critical role in human and social development
}

\section{Editorial Introduction to the Special Issue}

\author{
Saïd Assar
}

Institut Telecom, Telecom Business School, Department of Information Systems, 9 rue C. Fourier, 91011 Evry, France. E-mail: said.assar@it-sudparis.eu

Redouane El Amrani

Reims Management School, Management and Decision department, 59 rue P. Taittinger, BP 302, 51061 Reims Cedex, France. E-mail: redouane.elamrani@reims-ms.fr

Richard T. Watson

Department of MIS, Terry College, University of Georgia, Athens GA 30602-6273, USA. E-mail: rwatson@terry.uga.edu

Nelson Mandela, former South African President and Noble Laureate, observed that, "Education is the most powerful weapon which you can use to change the world." He left unanswered two questions: why do we want to change the world and what is it that needs to be changed. The articles in this special issues address the questions of how ICTs can enable education to change or improve the lives of people, important educational goals in all parts of the world, but particularly so in developing regions and underserved communities.

In order to achieve development, measurable improvements in people's lives have to be considered. Theses changes can be assessed in terms of social, economical and political development. In many regions of the world, there is an urgent need to raise living standards by providing a sustainable access to modern infrastructures in terms of water, electricity, transport, to raise income generation and job creation, to solve conflict, establish peace and limit access to weapons, to address the needs of vulnerable and oppressed groups and to encourage political systems based on democracy and the guarantee of human rights. However, what might be the most important thing to change is access to education. In many countries, access to education has become a strong focus of their governments. The need for economic and social development is a strong driver for governments and other interested institutions to invest in educational reform.

Education involves transmission of knowledge, accurate thinking, skills, habits and shared values. It is one of the main keys to social and economic development and improvements in human welfare as it is instrumental to transforming humans and their ways of life and death, and to improve their natural and artificial environment. As global economic competition grows sharper, education becomes an important source of competitive advantage, closely linked to economic growth. Providing education to everyone is a continuing challenge for developing regions and countries. It is universally recognized as a fundamental building block for human development and poverty reduction. To be effective, it requires appropriately trained human resources, specific material infrastructures, and adequate organizational guidelines and institutions. It requires also a long term strategic vision together with a strong and persistent political will.

The underserved regions of the world face many constraints in delivering education to the right people at the right time. Budgets are always tight, educational material is unavailable, human resources for teaching are scare and the best teachers rarely want to work in remote rural areas. All these factors have encouraged an interest in the use of information and communications technology (ICT) to deliver education and training. The significance of ICT is a recurrent theme in the global economy. ICT can play a significant role in generating economic growth. Gholami et al. (2010) found that investment in ICT, education, and economic literacy can play a significant role in equalizing opportunities for marginalized groups and communities. Their adoption and large-scale diffusion are recognized as a strong enabler for development but do not lead deterministically to economic growth. 
However, the issue of the direction of causality in the context of developing countries is still ambiguous, not fully understood, and needs to be formally addressed. Many studies show the importance of the local context and the importance of adapting IT-based practices when implementing them (Sahay \& Walsham, 2006). Implementing ICT In education is one of the major challenges facing developing countries as it is impossible to imagine future learning environments that are not supported, in one way or another, by ICT. The importance of the introduction of ICT into education systems is linked to the pressure on societies and economies to respond dynamically to globalization. ICTs are recognized to have the potential to reduce barriers to education for many as they can provide the underserved and geographically and culturally disadvantaged with access to educational resources.

Moreover, the adoption of ICT by education has often been seen as a way to contribute to educational change (enable reform or better management of education systems), better prepare students for the information age, improve learning outcomes and the skills of learners and prepare them for the information society. These initiatives are helping also to bridge the so-called digital divide: the gap between those who have access to and control of technology and those who do not. It is a new expression of the traditional technological dualism between rich and poor countries (Margarita et al., 2009). Some authors consider the failure to use ICT is itself a result of the digital and knowledge divides that exist.

This situation raises the following question: could developing countries and underserved regions accelerate national development efforts by simply installing more computers, educational software, and Internet access in their educational system? The findings bring to light contradictory results and the difficulties of such projects. Some research has shown that ICTs are used differently in underserved regions in terms of their goals for the introduction of ICT and in the pathways they have chosen to achieve those goals (Cairncross \& Pöysti, 2003; Reynolds, 2001). Schools can use ICT to merely access existing information and knowledge, rather than as part of a new 'transformative' pedagogy of teaching and learning. The effective use of ICT is harder than was initially expected. Many teachers in developing regions are often minimal users or non-users of ICT in their classrooms.

Empirical evidence has uncovered many limitations on the value returned by investments in ICT in education (Cuban, 2001). There are many reasons explaining this situation: a lack of capacity in third world countries in general to build, maintain, and utilize ICT to address educational needs, lack of ICT policy, poor ICT project management and corruption. Perceived difficulty in the integration of ICT in education has led to ineffective implementation, adoption of different systems and standards, duplication of effort, and waste of technology resources. Consequently, some of the earlier enthusiasm for educational ICT has waned. The cost of adopting ICT including acquiring hardware and software, setting up telecommunication networks, and the maintenance and repair of facilities is often prohibitive for developing countries. Given the low per capita income and declining standards of living, many policy makers focus policy formulation and policies on meeting the basic needs of the poor. The use of OER (Open Educational Resources) (J ohnstone, 2005) and OSS (Open Source Software) could be an alternative option that allows users to freely create and distribute software and educational resources without the prohibitive costs or licensing limitations.

There is practical importance to understanding the reasons for this non-use in relation to teacher and students' age, the subjects being taught, geographical, social, and cultural context. Several researchers argue that the development of effective ICT programs in education depends on a complex network of other social and economic factors that restrains developing countries from utilizing ICTs (Kendall et al., 2006). Van Reijswoud (2009) argues that ICT projects in developing countries become successful when adapted to local conditions and introduce the appropriate technology to increase the success of such projects. In other words, the educational effectiveness of ICTs in undeserved countries will depend on several variables, including the appropriate design of software and hardware, the training and attitude of instructors, and the realization that different students have different requirements. It also requires a willingness to experiment with effective use of ICT in education through pedagogical techniques that are different from traditional classroom teaching.

While there is a substantial literature on the possible determinants of ICT in changing and modernizing educational systems and ways of learning in developed countries, scientific evidence of the concrete contributions of ICTs to the learning domain is less evident in developing countries. A recent report by the World Bank's Information for Development Programme (Trucano, 2005) 
specified that there is limited data to support the perceived benefits from ICT and very little systematic researches about how ICT is actually used in the classroom and even less about its impact on educational outcomes, social behaviour, and the performance indicators to monitor the use and impact of ICTs in education.

Given the increasing strategic importance of ICT in education in developing countries, there is a pressing need for additional work and further investigation and research to be done in this area. For ICTs become effective and integral tools in education, their impact needs to be quantitatively and convincingly demonstrated.

\section{Special issue on ICT and education in underserved regions}

This special issue investigates ICT and education in undeserved regions and developing countries through multiple aspects: what is the actual status of ICT usage for education? How can ICT help in providing high quality training programs adapted to the specific needs of students and trainees? What are the problems and barriers related to ICT usage for education? How do the specific social, economic, cultural, and geographical contexts in developing regions impact the usage of ICT in education? We sought significant case studies, theoretical, exploratory, or position papers, which could help in understanding these problems and in shaping good practices and recommendations for educational practitioners and researchers interested in ICT usage in the classroom.

The preliminary ideas behind this special issue were initially experimented with in a workshop entitled "Information Systems research and education in developing countries" which was organized at ICIS 2008 in Paris (Assar, EL Amrani, 2008). The objective of this workshop was to gather researchers to discuss and exchange experiences and ideas concerning ICT and information systems education in developing countries. Submissions were allowed in either English or French, and the presentations were in English. The workshop attracted 42 submissions from 31 countries, of which 18 were accepted for presentation and published in the workshop's proceedings. 36 participants attended the workshop. The majority of the papers were empirical and practical and tackled a variety of topics involving IS and IT educational projects and uses in developing countries.

This workshop was organized with the help of UNESCO Israel who provided a USD 10,000 budget, which was used to pay ICIS conference fees and hotel expenses for workshop participants from low and upper-middle income countries. Participants were selected based on the quality of their research as well as the merits (candidates have academic career in Information Systems; some publications on national and international IS journals). We are particularly thankful to Professor Dov Te'eni (Tel-Aviv University, Israel) and Professor Frantz Rowe (Nantes University, France) who initiated the workshop project, worked on getting funding, and helped in organizing the workshop in the context of ICIS 2008 conference.

As part of the workshop organization, we were encouraged by ITD's Editor-in-Chief Saj da Qureshi to plan this special issue. Although it targeted authors of papers presented at the workshop, the issue was open to any submission and the Call For Papers was widely diffused. Twelve manuscripts were submitted, of which three were from workshop authors.

\section{Organization of the special issue}

This special issue has four research papers and one view from practice. The papers cover different topics related to ICT and education. We now briefly summarize each of these papers and discuss its relevance to the questions raised in the first section of this paper.

The first contribution, by Khitam Shraim and Zuheir Khlaif, is entitled "An e-learning approach to secondary education in Palestine: Opportunities and challenges". In a region where the ongoing Palestinian-Israeli conflict has deeply affected population movements and has separated student and teachers from their educational institutions, ICT based distance learning has become a necessity to improve access to quality education for all Palestinians students. While substantial investment and considerable efforts have been made to develop e-learning approaches since 2002, its introduction into primary and secondary education is still in the planning process. Through a mixed quantitative and qualitative study, this paper explores the potential of e-learning methods to 
enhance the educational process and to provide continuous learning for secondary students in Palestine. An interactive Web-based application prototype called the Alaws Educational Network (AEN) provides a variety of methods for a student-centered learning process, including virtual classrooms, discussion forums, and e-training courses. Students and teachers were asked to evaluate different aspects of the AEN in terms of usefulness, self-efficacy, willingness, and challenges as indications of their ability and readiness to embrace e-learning. The results show that both students and teachers have positive attitudes towards the usefulness of e-learning methods but that they might not yet be ready to adopt them. Open comments of respondents pointed to issues that need to be addressed related to existing digital divide and technical limitations of the network, lack of elearning skills, lack of autonomy, poor time management and workload pressure. They also pointed to more complex issues concerning institutional support and language barriers.

This paper shows that although final users are willing to embrace ICT supported distance teaching and learning, other problems remain: top managers are not fully aware of its potential, best practices need to be disseminated, the necessity of developing IT literacy programs, digital divide between schools in urban and those in rural areas. Authors consider that a holistic approach to the problem needs to be developed so that the combination of social, technical and organizational factors contributes to the success of the project.

The second paper makes a contribution to adaptability of education to people, and explores the impact of language and cultural barriers on the success of introducing ICT in the classroom. It is authored by Greta Björk Gudmundsdottir and is entitled "When does ICT support education in South Africa? The importance of teachers' capabilities and the relevance of language". In a region that once has been a highly segregated nation, and despite emphasis on the equal rights of all ethnic groups as mentioned in the new South African progressive constitution, South Africa remains a country of great disparities. The paper seeks to understand how cultural aspects intertwine and possibly influence computer use in South African schools. The main focus is on a broad understanding of the concept of digital divide, and how cultural complexity, with special emphasis on language, can affect the digital divide in schools that already have material access to ICT.

One of the distinctive aspects of cultural complexity in South Africa is the language dimension. The country has 11 official languages, and the languages used in South Africa are related to status, class, and political context. While learners are taught in their mother tongue in the first three grades of school (grade one to three), learners with African home languages participate in English or possibly Afrikaans classes for the rest of their school attendance. Strong connection has been suggested in some research works between the home language as the language of instruction and learners' positive learning processes. So for the purpose of her research, the author develop a broad definition of the digital divide concept which, beyond having or not access to computers and the internet, includes linguistic and cultural divide as the dominance of the English language and culture restrain access to and use of knowledge.

The study is a comparative case study and is based on fieldwork in seventh-grade classes in four primary schools in Cape Town. The learners answered a questionnaire regarding their ICT use and skills, and interviews were conducted with learners, teachers, and principals. In the findings, two underlying explanations have been discussed when seeking to answer the question of what is influencing the digital divide in schools that already have material access to computers: (i) the importance of raising the ICT capability of the teachers and their opportunities to obtain training, and (ii) the role of language in conjunction with learners' ICT use. It is argued that the challenges of languages in South African schools can exacerbate or maintain the digital divide among learners who are already disadvantaged due to a range of social inequalities. The author considers that ICT needs to be put in a local context, which includes use in a familiar language so that learners can fully master the use of ICT in today's global knowledge society. Moreover, she suggests that greater opportunities for teacher training are needed in order to enhance culturally sensitive and appropriate ICT integration based on local needs and capacity.

The third paper is by Godfred Bonnah Nkansah and Tim Unwin is entitled «The contribution of ICTs to the delivery of Special Educational Needs in Ghana: practices and potential". Those with special educational needs are underserved in many communities, irrespective of the stage of development of the economy. Using Ghana as the site for their research, Nkansah and Unwin investigate how ICT can support those with special educational needs (SEN). To address this issue, the authors used qualitative interviews, focus groups and questionnaire. They illustrate the power of ICT to benefit those with major disabilities and note that ICT can reduce their marginalization, but this is an issue rarely considered in developing economies where there is so much competition for resources, 
particularly in the education sector. Moreover, the other issue is about the cost and the inadequate human and physical infrastructure at the school level to accommodate and manage such technologies effectively. The contribution of this article is to raise awareness of the potential of ICT to educate one of the most underserved communities in the world. It is a call for governments across Africa, and indeed the world, to examine how assistive technologies can help those with SEN to be supported to achieve the dignity associated with education: "The time has come for a globally concerted effort to place accessibility at the heart of ICT for education initiatives".

The fourth paper in this issue, written by Negash Solomon is entitled "Learning Assessment of a Videoconference-based Training: Lessons from medical training between US and Ethiopia". The main research question guiding this study was whether videoconferencing can serve as an effective medium to facilitate training programs conducted between high and low-income countries? To address this issue, the authors focused on a two-way videoconferencing training program conducted between the US and Ethiopia. Specifically, four videoconference locations in the US were connected to a similar center in Ethiopia in order to provide high level HIV/ AIDS medical management training to Ethiopian medical professionals. In the context of developing countries, this paper raises an interesting and relevant issue: given that knowledge experts are typically concentrated in highincome countries, how can we increase the knowledge of medical professionals in underserved communities through a videoconference-based training? In the health sector, ICT can be a cornerstone for efficient and effective services. Over the last decade, the need to develop and organize new ways of providing health services has been accompanied by major advances in ICT, enabling better support for health services and systems and simultaneously improving global awareness of health issues. As a consequence, the World Bank and UNESCO have insisted on member nations developing long term e-health strategies. In the context of underserved countries, this approach can potentially solve problems such as the shortage of skills of health professionals and the training of medical workers. The results of this study indicate that the videoconference-based training had a positive impact on Ethiopian physicians' attitudes and resulted in significant learning gains. It shows that videoconference-based training can bridge the knowledge gap in low-income countries by linking them with high-income countries and may become the catalyst for developing advanced telemedicine services. Nevertheless, while this potential is apparent, it is not yet clear whether it can be realized in an environment in which there are human resource constraints at both the sending and receiving sites. This study also identified constraining and promoting factors of the videoconference-based training. The paper concludes with three lessons learned in the following three areas: cultural context, IT infrastructure, and sustainable community. Each lesson has implications for research and practice.

A view from practice paper by Paolo Brunello provides a critical review of the success factors of ICT projects in developing regions, and is entitled "ICT for Education projects: a look from behind the scene". Based on the author's direct experience in multiple ICT for education projects in Burundi, he argues that factors other than lack of maintenance and local ownership of technology can have strong impact on the success or failure of such projects. A first identified factor is bureaucracy compliance, as the donor from developed countries often expects a high level of procedures' traceability. The result is a bureaucratic burden which is due to critical infrastructural limitations in the developing countries. This can lead to a bureaucratic paradox where administrative rules are trespassed in different ways so that to carry out the planned activities. A second identified factor is related to the predefined roles played by actors on the ground. "Developer" and "developee" are constantly negotiating their respective roles and mutually reconfirming them, and this sets the stage for a predefined, often unadapted, way of transmitting knowledge and running development projects. A third identified factor is transaction costs and relates to running and maintaining technological infrastructures implemented during the development project. Running costs expenditures (i.e specific printer cartridges) are generally intended to be provided by the beneficiaries, and this rapidly can become a major reason for ICT project to fail on the long run. A fourth identified factor is the bias towards setting up physical infrastructures over setting educational use of these infrastructures. This also can be a strong reason for ICT for education projects to fail as training and usage are not emphasized enough. To conclude, the author calls for a radical change in the overarching mindset dominating both aid and education, moving away from the "medical metaphor" with donor countries playing the doctors and recipient countries the patients. He suggests a constructionist approach where the role of donor countries is one of a mentor and a supervisor of technological transfer, a facilitator for peer learning and a partner for knowledge sharing. 


\section{Acknowledgments}

We acknowledge the authors of all the submitted articles and all who helped in the review process of the special issue. We particularly would like to acknowledge the work and efforts of the following reviewers for this special issue: Patience Akpan-Obong (Arizona State University, USA); Ghada Alaa (American University at Cairo, Egypt); Mokhtar Amami (Royal Military College of Canada); Reza Barkhi (Virginia Tech, USA); Madeleine Besson (Telecom Business School, France); Cécile Clergeau (University of Angers, France); Sam Dzever (Telecom Business School, France); Zarinah M. Kasirun (University of Malaysia); Beatriz B. B. Lanza (Companhia de Informática do Paraná - Celepar, Brazil); Allyson Macdonald (University of Iceland); Ravishankar Mayasandra (Loughborough University, UK); Becky Matter (University of Washington, USA); Philip Musa (University of Alabama at Birmingham, USA); Ståle Angen Rye (Agder University College, Norway); Matti Rossi (Aalto University School of Economics, Finland); Elmarie Venter (University of Pretoria, South-Africa); Rebecca Walton (University of Washington, USA); Sidne Ward (University of Missouri, USA); Yingqin Zheng (London School of Economics, UK). We also give a special acknowledgement to Sajda Qureshi, the editor-inchief of this journal, who gave encouragement, support and advice throughout the development of the special issue.

\section{References}

Assar, S., \& El-Amrani, R. (2008). Information Systems research and education in developing countries. December 14th, 2008, Paris, France. Available at http://www-public.itsudparis. eu/ assar/ pre-ICISO8/.

Billon, M.,_Rocio, M., \& Lera-Lopez, F. (2009). "Disparities in ICT adoption: A multidimensional approach to study the cross-country digital divide", Telecommunications Policy, 33, pp. 596-610.

Cairncross, F., \& Pöysti, K. (2003). ICTs for education and building human capital. International Telecom Union. Available at http:// www.itu. int/osg/spu/visions/.

Cuban, L. (2001). Oversold and underused: Computers in the classroom. Harvard University Press.

Gholami R., Anon Higon D., Hanafizadeh P. and Emrouznejad A. (2010). Is ICT Key to Development?. J ournal of Global Information Management, 18(1): 66-83.

Glenn, J. C., \& Gordon, T. J. (1998). State of the future: Issues and opportunities. Millenium Project Publication, American Council for the United Nations University.

Human Development Report. (2001). Making New Technologies Work for Human Development. UN Development Program. Available at http://hdr.undp.org/ en/reports/global/hdr2001/.

Johnstone, S. M. (2005). Open educational resources serve the world. Educause Review. http:// www. educause. edu/ apps/ eq/ eqm05/ eqm0533. asp.

Kendall K. E., Kendall J. E., \& Kah M. M. O. (2006). "Formulating Information and Communication Technology (ICT) Policy Through Discourse: How Internet Discussions Shape Policies on ICTs for Developing Countries". Information Technology for Development, 12 (1) 25-43.

Reynolds, D. (2001). ICT in Education: The Future Research and Policy Agenda, Keynote presentation at conference on "Building an ICT Research Network," hosted by Becta J une 2001. Available at dir/downloads/page documents/research/reynolds. pdf

http:// research. becta. org. uk/ upload-

Sahay, S., \& Walsham, G. (2006) "Scaling of health information systems in India: challenges and approaches." Information Technology for Development, 12(3): 185-200.

Trucano, M. (2005). Knowledge Maps: ICT in Education. What do we know about the effective uses of information and communication technologies in education in developing countries?. Washington, DC: infoDev / World Bank. Available at: http:// www.infodev. org/ en/ Publication. 8. html. 
Van Reijswoud, V. (2009). "Appropriate ICT as a Tool to Increase Effectiveness in ICT4D: Theoretical considerations and illustrating cases". EJISD, 38(9):1-18. Available at http:// www. ejisdc. org/ ojs2/ index. php/ ej isdc.

Saïd Assar is Associate Professor of Information Systems at Institut Telecom's Business School, Evry, France. He received his Ph.D. in computer science from Pierre \& Marie Curie University in Paris. He teaches MIS, Information Systems methodologies and software engineering tools at graduate and postgraduate level. Dr. Saïd Assar areas of research interest are in IS engineering, IS management and ICT usage, he has co-edited a book about e-government and has published several research papers on different topics related to IS modeling, IS design, public e-procurement and e-learning.

Redouane El Amrani is Associate Professor in Information Systems at Reims Management School, France. He received a PhD from Nantes University and an MS from Versailles University, France. His research interests include ERP implementation and use in large firms, the impact of ERP systems and $\mathrm{Bl}$ on cross-functionality, competence center and related topics. He has published in International and French journals (Information System Journal, Systèmes d'Information et Management; Revue Française de Gestion; Gérer et Comprendre). He has presented also papers at conferences such as ICIS, ECIS and AIM (French Conference on IS). He served as Co-chair of the 14th AIM French Conference 2009, Associate Editor at ICIS 2008, and Track Chair at the MCIS in 2007.

Richard Watson is the J. Rex Fuqua Distinguished Chair for Internet Strategy in the Terry College of Business at the University of Georgia. He is a consulting editor for John Wiley \& Sons, a former President of the Association for Information Systems, a visiting professor at the University of Agder in Norway, international coordinator the Addis Ababa University PhD in IS, and co-leads the Global Text Project, which provides free electronic textbooks for students in developing economies. His research interests include Energy Informatics and IS leadership. 